Article

\title{
Proteomics Analysis Reveals Non-Controlled Activation of Photosynthesis and Protein Synthesis in a Rice $n p p 1$ Mutant under High Temperature and Elevated $\mathrm{CO}_{2}$ Conditions
}

\author{
Takuya Inomata ${ }^{1}$, Marouane Baslam ${ }^{2} \mathbb{D}$, Takahiro Masui ${ }^{1}$, Tsutomu Koshu ${ }^{1}$, \\ Takeshi Takamatsu ${ }^{1,2}$, Kentaro Kaneko ${ }^{1}$, Javier Pozueta-Romero ${ }^{3}$ and Toshiaki Mitsui ${ }^{1,2, *}$ \\ 1 Graduate School of Science and Technology, Niigata University, 2-8050 Ikarashi, Niigata 950-2181, Japan; \\ f14m005a@mail.cc.niigata-u.ac.jp (T.I.); zoujoukikou@gmail.com (T.M.); \\ tsutomu58koshu@hotmail.co.jp (T.K.); ttakamatsu@agr.niigata-u.ac.jp (T.T.); k-neko@gs.niigata-u.ac.jp (K.K.) \\ 2 Department of Biochemistry, Niigata University, Niigata 950-218, Japan; mbaslam@gs.niigata-u.ac.jp \\ 3 Instituto de Agrobiotecnología (CSIC, UPNA, Gobierno de Navarra), Mutiloako Etorbidea Zenbaki Gabe, \\ 31192 Mutiloabeti, Nafarroa, Spain; javier.pozueta@unavarra.es \\ * Correspondence: t.mitsui@agr.niigata-u.ac.jp; Fax: +81-25-262-6641
}

Received: 15 August 2018; Accepted: 3 September 2018; Published: 7 September 2018

\begin{abstract}
Rice nucleotide pyrophosphatase/phosphodiesterase 1 (NPP1) catalyzes the hydrolytic breakdown of the pyrophosphate and phosphodiester bonds of a number of nucleotides including ADP-glucose and ATP. Under high temperature and elevated $\mathrm{CO}_{2}$ conditions $\left(\mathrm{HT}+\mathrm{ECO}_{2}\right)$, the npp 1 knockout rice mutant displayed rapid growth and high starch content phenotypes, indicating that NPP1 exerts a negative effect on starch accumulation and growth. To gain further insight into the mechanisms involved in the NPP1 downregulation induced starch overaccumulation, in this study we conducted photosynthesis, leaf proteomic, and chloroplast phosphoproteomic analyses of wild-type (WT) and $n p p 1$ plants cultured under $\mathrm{HT}+\mathrm{ECO}_{2}$. Photosynthesis in $n p p 1$ leaves was significantly higher than in WT. Additionally, npp1 leaves accumulated higher levels of sucrose than WT. The proteomic analyses revealed upregulation of proteins related to carbohydrate metabolism and the protein synthesis system in $n p p 1$ plants. Further, our data indicate the induction of 14-3-3 proteins in $n p p 1$ plants. Our finding demonstrates a higher level of protein phosphorylation in $n p p 1$ chloroplasts, which may play an important role in carbohydrate accumulation. Together, these results offer novel targets and provide additional insights into carbohydrate metabolism regulation under ambient and adverse conditions.
\end{abstract}

Keywords: chloroplast; elevated $\mathrm{CO}_{2}$; heat stress; nucleotide pyrophosphatase/phosphodiesterase; (phospho)-proteomics; photosynthesis; protein phosphorylation; 14-3-3 proteins; Oryza sativa L.; starch; sucrose

\section{Introduction}

Changes in climate explain a major portion (32-39\%) of yield variability, which correspondingly may translate into large fluctuations in global crop production [1]. Climate change that alters photosynthetic rates may modify physiological responses, plant growth rates (and overall productivity), and resource uses. Therefore, the potential for physiological functioning to evolve in response to climate change will be a key indicator of plant resilience in future environments [2,3]. As they are mostly immobile, plants must adapt to their biotic and abiotic environments limiting or promoting productivity and carbon biosequestration. Photosynthesis can be critical to mitigating the effects of changing climatic conditions. Although the relationship between stomatal conductance, $\mathrm{CO}_{2}$ uptake, 
and photosynthesis fluctuates in nature, leaf photosynthesis is known to be highly correlated with stomatal conductance in rice [4,5]. Studies employing mutants deficient in a stomatal anion channel protein SLAC1 (Slow Anion Channel-associated 1) revealed that stomatal conductance is a major determinant of photosynthetic rate in higher plants [6,7]. Thus, terrestrial plants regulate $\mathrm{CO}_{2}$ uptake by stomatal switch in response to environmental and biochemical stimuli. The assimilated carbon is further converted to starch in the plastid stroma or to sucrose in the cytosol via sugar nucleotides. In rice leaves, it has been shown that the assimilated carbon is partitioned into sucrose rather than starch $[8,9]$. Under varying environmental conditions, plant growth and development have to be counterbalanced for defense and stress adaption. Notably, proportional changes in protein composition in response to environmental changes are a major cellular response to requirements of homeostatic adjustment and metabolic remodeling.

Starch is synthesized in plant leaves during the day from photosynthetically fixed carbon. It is then mobilized and thus constitutes an important carbon reserve as well as an energy source for plants and provides the major nutritional value of food crops. Starch biosynthesis occurs in plastids and requires several key enzymes $[10,11]$. Starch, probably the most important metabolite of plant carbohydrate metabolism, is an insoluble polyglucan produced by starch synthase (SS) using ADP-glucose as the sugar donor nucleotide. Among the many enzymes participating in plant nucleotide catabolism, the pyrophosphatase/phosphodiesterase (NPP) family members, including NPP1, actively catalyze the hydrolytic breakdown of the pyrophosphate and phosphodiester bonds of ADP-glucose [12-14]. In rice, six NPP genes (NPP1-6) have been identified and characterized [14]. The NPP genes are located on chromosomes 3 (NPP3), 8 (NPP1), 9 (NPP6), and $12(N P P 2,4,5)$ in the rice genome. Although NPP3 was exclusively localized in the endomembrane system [15], NPP1, 2, and 6 exhibited a dual localization in both the plastid and endomembrane systems $[13,16,17]$, as has been found for other plastidial glycoproteins [18-22]. Whereas NPP1 and NPP6 recognized nucleotide sugars, NPP2 did not recognize these compounds as substrates but preferentially hydrolyzed uridine diphosphate (UDP), ADP, and adenosine 5'-phosphosulfate (APS). NPP1 best hydrolyzed ADP-glucose, ADP-ribose, and ATP, while ADP and ADP-glucose were the best substrates for NPP6. Rice NPP genes showed tissue- and stage-specific expression [14,15]. Thus, it is possible to suppose that rice NPPs are engaged in multiple biological functions through the influence of the turnover of nucleotides and nucleotide derivatives. NPP1 is a major determinant of ADP-glucose pyrophosphatase (AGPPase) activity and can reduce the plastidic pool of ADP-glucose required for starch accumulation in rice [14]. Plant NPPs seem to play a crucial role in carbon flux by transporting carbon taken up from starch and from cell wall polysaccharide biosynthesis to other metabolic pathways in response to the physiological needs of the cell. We have previously shown that when the npp 1 null mutant is grown under different $\mathrm{CO}_{2}$ concentration and temperature conditions, NPP1 exerts a negative effect on plant growth and starch accumulation. This provided the first in vivo evidence for the role of NPP1 in the control of growth and reserve pool of carbohydrate in rice under fluctuating climatic conditions [14]. Recently, the presence of NPPs in the plastidial compartment was further confirmed $[13,15,16]$. Moreover, we have tentatively identified complex-type and pauci-mannosidic-type oligosaccharide chains with $\beta 1,2$-xylose and/or differential core $\alpha 1,3$-fucose residue(s) in rice NPP1, which provides strong evidence that the trans-Golgi compartments participate in the Golgi-to-plastid trafficking and targeting mechanism of NPP in rice [16]. Plants with a defective endoplasmic reticulum (ER) $N$-glycosylation pathway and $\mathrm{N}$-glycan maturation are associated with diverse phenotypes and are more sensitive to environmental conditions [23]. Nonetheless, the regulatory mechanisms of high temperature and elevated $\mathrm{CO}_{2}$-induced starch accumulation and growth stimulation in npp1 leaves are unknown. Herein, we highlight that the loss-of-function of NPP1 not only influences stomatal conductance, photosynthesis, and plants' storage of starch and sucrose but also impacts a set of proteins involved in carbohydrate metabolism and the protein synthetic system in rice leaves under high temperature and $\mathrm{CO}_{2}$ conditions $\left(\mathrm{HT}+\mathrm{ECO}_{2}\right)$. 


\section{Results and Discussion}

2.1. Knocking out NPP1 Decreases Leaf Temperature and Enhances Stomatal Conductance under High Temperature and Elevated $\mathrm{CO}_{2}$ Conditions

In order to examine phenotypic characteristics of the npp1 mutant, 60-day old wild-type (WT) and npp1 mutant rice plants were subjected to thermographic analysis in a spacious Biotron (length $4.5 \times$ width $4.5 \times$ height $1.8-2.2 \mathrm{~m}$ ) with varying temperatures $\left(28\right.$ and $\left.33{ }^{\circ} \mathrm{C}\right)$ and $\mathrm{CO}_{2}$ concentrations (40 and $160 \mathrm{~Pa}$ ) under natural sunlight. As shown in Figure 1, the leaf temperatures of WT and npp1 plants increased concomitantly with the $\mathrm{CO}_{2}$ concentration irrespective of temperature conditions. Notably, the leaf temperature in npp1 plants was apparently lower than in WT plants at all temperature and $\mathrm{CO}_{2}$ conditions examined (Figure 1). We further examined the flag leaves' temperatures in WT and npp 1 under the different temperature $\left(28\right.$ and $\left.33^{\circ} \mathrm{C}\right)$ and $\mathrm{CO}_{2}$ conditions $(40$ to $200 \mathrm{~Pa}$ ) under fully controlled environmental chamber conditions (width $64 \times$ width $56 \times$ height $108 \mathrm{~cm}$ ) using a portable photosynthesis measuring system (Figure 2A). The leaf temperatures of both WT and npp1 gradually increased as $\mathrm{CO}_{2}$ concentrations increased, irrespective of temperature conditions, and reached saturation at $160 \mathrm{~Pa}$ (Figure $2 \mathrm{~A})$.
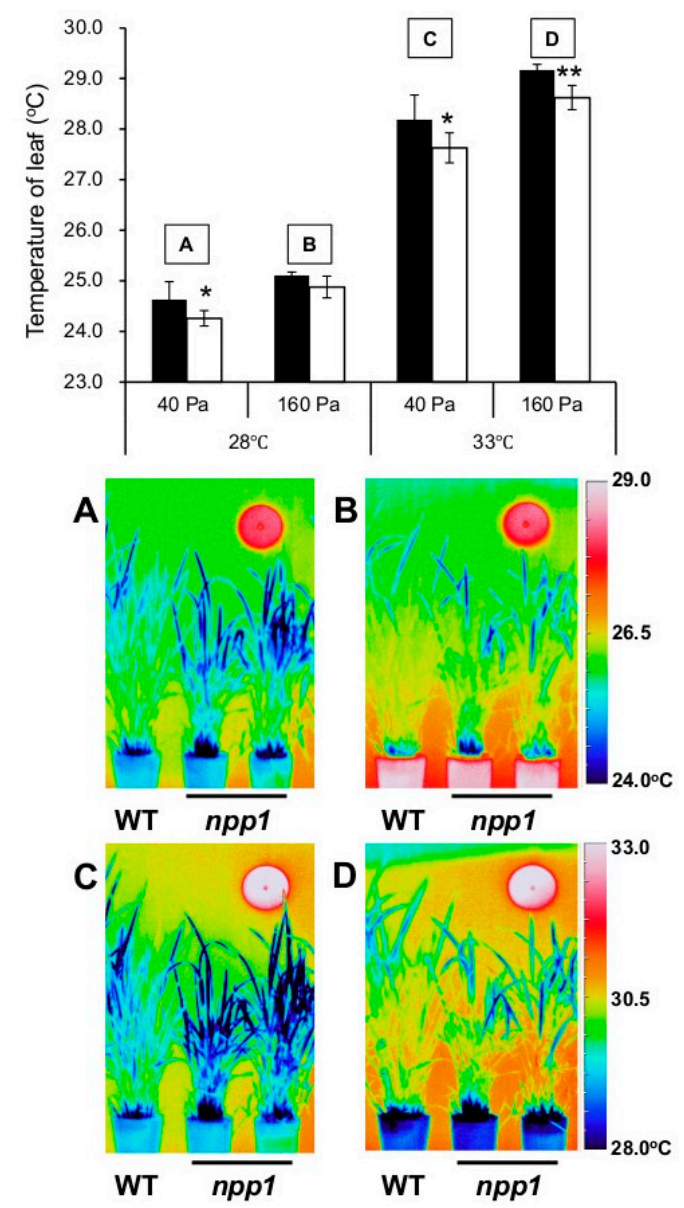

Figure 1. Leaf temperatures of WT and npp1 mutant plants under different temperatures and $\mathrm{CO}_{2}$ concentrations in Biotron's environmental conditions. WT (filled bars) and npp1 (open bars) plants grown for 60 days under normal conditions (14 h light/10 h dark: $28 / 23{ }^{\circ} \mathrm{C}, 40 \mathrm{~Pa} \mathrm{CO}_{2}$ ) after germination were subjected to thermographic analysis of their leaf temperatures under different temperature and $\mathrm{CO}_{2}$ conditions: (A) $28^{\circ} \mathrm{C}, 40 \mathrm{~Pa},(\mathbf{B}) 28^{\circ} \mathrm{C}, 160 \mathrm{~Pa},(\mathrm{C}) 33^{\circ} \mathrm{C}, 40 \mathrm{~Pa}$, and (D) $33^{\circ} \mathrm{C}$, $160 \mathrm{~Pa}$. Values in upper panel show the means \pm standard deviation (s.d.) $(n=5)$. Asterisks indicate significant differences by Student's $t$-test $\left.{ }^{*}, p>0.05 ;{ }^{* *}, p>0.01\right)$. Lower panels represent the thermographic images. WT: wild-type. 
A
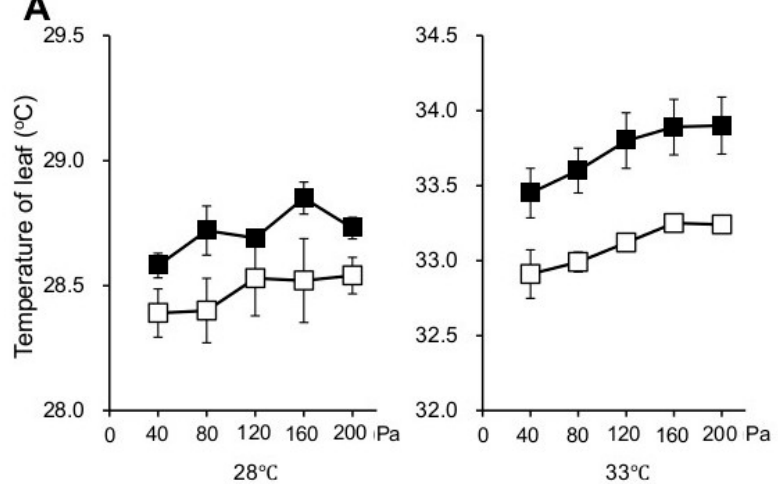

B
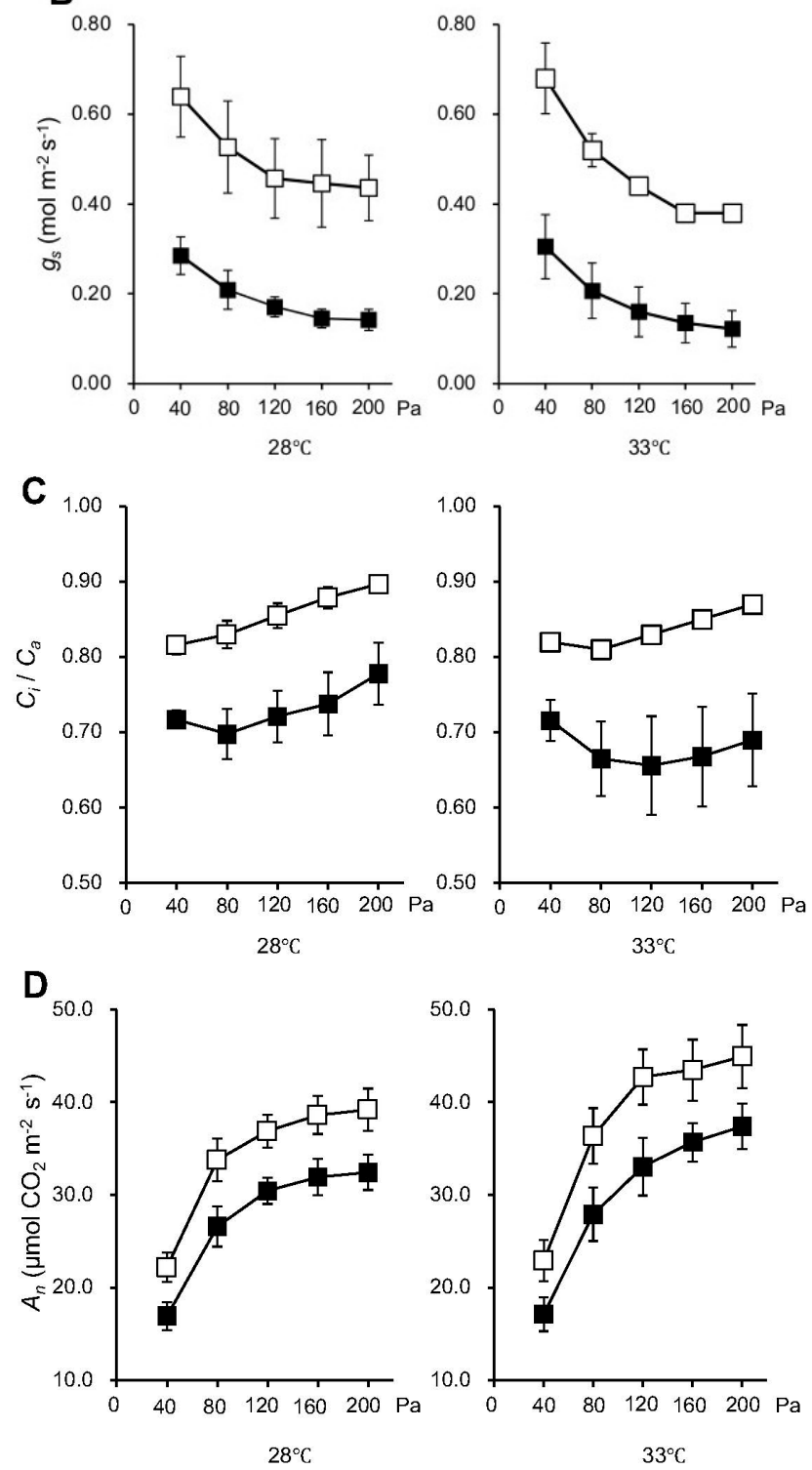

Figure 2. Changes in temperatures, $g_{s}, C_{i} / C_{a}$, and $A_{n}$ of WT and npp 1 mutant plants under different temperatures and $\mathrm{CO}_{2}$ concentrations in a controlled growth chamber. Top leaves of main culm of WT

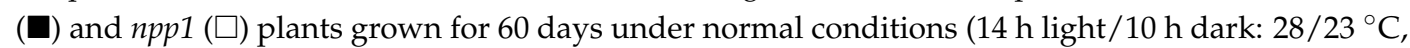
$\left.40 \mathrm{~Pa} \mathrm{CO}_{2}\right)$ were subjected to measurements of temperature (A), stomatal conductance to water $\left(g_{s}\right)(\mathbf{B})$, ratios of internal $\left[\mathrm{CO}_{2}\right]$ to ambient $\left[\mathrm{CO}_{2}\right]\left(C_{i} / C_{a}\right)(\mathbf{C})$, and photosynthetic rates $\left(A_{n}\right)(\mathbf{D})$ under the following conditions: temperature, 28 and $33{ }^{\circ} \mathrm{C} ; \mathrm{CO}_{2}, 40$ to $200 \mathrm{~Pa}$; relative humidity, 50\%; light, $1000 \mu \mathrm{mol} \cdot \mathrm{photons} \cdot \mathrm{m}^{-2} \cdot \mathrm{s}^{-1}$. Values show the means \pm s.d. $(n=3)$. 
The reduction of leaf temperature in $n p p 1$ strongly suggested that knocking out NPP1 increases the transpiration rate of the plant. This inference was corroborated by the analysis of the stomatal conductance $\left(g_{s}\right)$ under varying temperatures and $\mathrm{CO}_{2}$ concentrations. As shown in Figure 2B, elevated $\mathrm{CO}_{2}$ concentrations caused partial stomatal closure in the two genotypes. No significant differences were observed in the $g_{s}$ values between the two temperature regimes. Notably, the $g_{s}$ values in $n p p 1$ plants were higher than in WT plants under all temperatures and $\mathrm{CO}_{2}$ concentrations.

Previous reports have shown that high $\mathrm{CO}_{2}$ decreases $g_{s}$ in a temperature-independent manner [6,24-28]. Changes in $g_{s}$ value in the npp1 mutant under different temperature and $\mathrm{CO}_{2}$ conditions were similar to those in WT, indicating that the stomatal regulatory mechanisms of npp1 work normally.

\subsection{Knocking out NPP1 Enhances Photosynthetic Capacity under High Temperature and Elevated $\mathrm{CO}_{2}$ Conditions}

The high $g_{s}$ values observed in the npp1 mutant suggested that the lack of NPP1 expression enhances $\mathrm{CO}_{2}$ diffusion. In line with this presumption we found that, irrespective of the temperature regime, the intercellular-to-atmospheric $\mathrm{CO}_{2}$ mole fraction $\left(C_{i} / C_{a}\right)$ in npp1 was higher than in WT plants at all atmospheric $\mathrm{CO}_{2}$ concentrations (Figure 2C). Consistently, npp1 plants had higher net rates of $\mathrm{CO}_{2}$ assimilation $\left(A_{n}\right)$ than WT plants at all atmospheric $\mathrm{CO}_{2}$ levels in the two temperature regimes (Figure 2D).

Whether enhanced photosynthesis in $n p p 1$ plants is solely the consequence of enhanced $\mathrm{CO}_{2}$ diffusion was investigated by measuring $A_{n}$ under varying $C_{i}$. As shown in Figure 3 , these analyses revealed that the npp 1 mutant showed higher $A_{n}$ values than WT plants at all $C_{i}$ levels. In rice plants, sucrose is the primary transport sugar and plays a central role in plant growth and development. As expected, levels of sucrose in $n p p 1$ mutants were found to be significantly higher compared with their control WT in any incubation conditions (Figure 4). Previously, the npp1 mutants have been shown to accumulate starch under high $\mathrm{CO}_{2}$ concentration conditions [14]. Thus, it is evident that NPP1 exerts a negative effect on carbohydrate accumulation under $\mathrm{HT}+\mathrm{ECO}_{2}$. In these conditions, the npp 1 mutants increase photosynthesis and the Calvin-Benson cycle (as detailed below), the latter via increased accumulation of Rubisco activase, enabling $n p p 1$ plants to adjust downstream reactions such as sucrose biosynthesis and phloem loading to the increased leaf assimilation. These results indicate that the stimulation of photosynthesis in the npp 1 mutant was caused by both stomatal conductance and non-stomatal conductance related causes. Stomata opening and closure occurs via changes in the turgor pressure of guard cells, and the physiological event is regulated by ion and sugar movements in the guard cells $[6,29,30]$. Increased $\mathrm{CO}_{2}$ concentrations enhance anion channel activity (which has been proposed to be a means of mediating the efflux of osmoregulatory anions from guard cells) [31], causing stomatal closure in rice leaves (Figure 2B, [32]). In $n p p 1$ guard cells, the accumulation of sucrose probably causes stomata opening, further activating the photosynthesis of $n p p 1$ leaves under the elevated $\mathrm{CO}_{2}$. The NPP1 enzyme, which hydrolyzes sugar nucleotides and ATP, is localized and functions in the chloroplast of rice, therefore, the contents of ATP in chloroplasts should be increased. The high level of ATP in npp1 chloroplasts would boost the turnover of the Calvin cycle and actively convert $\mathrm{CO}_{2}$ to starch and sucrose. In fact, in npp 1 null mutants grown under different temperature conditions and $\mathrm{CO}_{2}$ concentrations, a negative effect on the reserve pool of carbohydrates is seen. In this case, NPP activity may occupy a central position in carbon metabolism and its metabolic output to provide products such as the amino acids and lipids necessary for increasing plant biomass. 

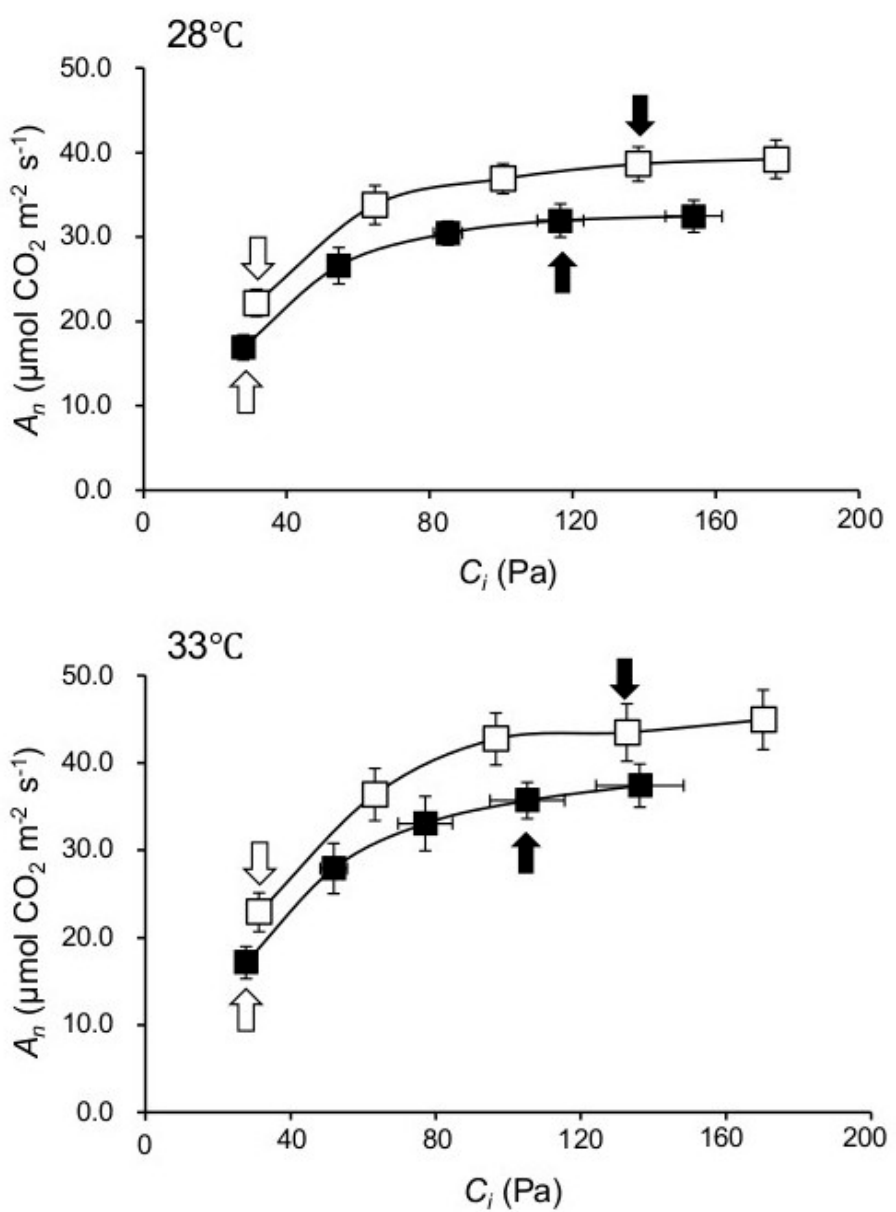

Figure 3. Photosynthetic rates at different intracellular $\left[\mathrm{CO}_{2}\right]\left(A_{n} / C_{i}\right.$ curve $)$ of leaves from WT and $n p p 1(\square)$ plants. The results of Figure 2 were used to draw an $A_{n} / C_{i}$ curve. Open and filled arrows represent the data obtained at $C_{a}$ of 40 and $160 \mathrm{~Pa}$, respectively.

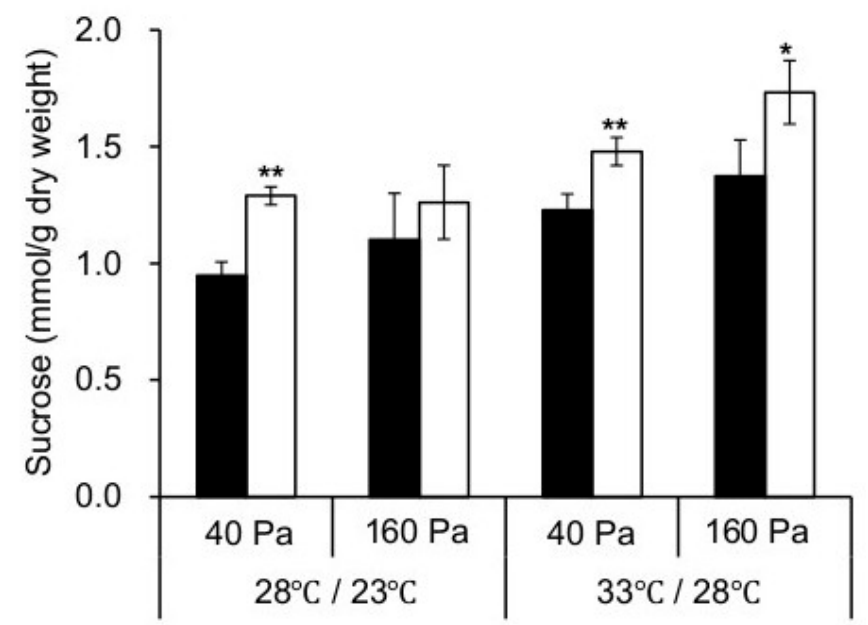

Figure 4. Sucrose accumulation in leaves of WT and npp1 mutant plants. WT (filled bars) and npp1 (open bars) plants grown for 60 days under normal conditions $\left(28 / 23{ }^{\circ} \mathrm{C}, 40 \mathrm{~Pa} \mathrm{CO}_{2}\right)$ were further incubated under different temperatures and $\mathrm{CO}_{2}$ concentrations. At the end of a light cycle, the leaves of the WT and the $n p p 1$ mutant plants were subjected to sucrose assays. Values show the means \pm s.d. $(n=3 \sim 5)$. Asterisks indicate significant differences by Student's $t$-test $\left({ }^{*}, p>0.05 ;{ }^{* *}, p>0.01\right)$. 


\subsection{Proteomic Characterization of npp1 Leaves under High Temperature and Elevated $\mathrm{CO}_{2}$ Conditions}

To characterize changes in the proteome of npp1 leaves under $\mathrm{HT}+\mathrm{ECO}_{2}$, we carried out a quantitative proteomic analysis. Proteins extracted from leaves of WT and npp 1 plants grown under normal $\left(28 / 23^{\circ} \mathrm{C}\right.$ and $\left.40 \mathrm{~Pa} \mathrm{CO}\right)$ and $\mathrm{HT}+\mathrm{ECO}_{2}\left(33 / 28^{\circ} \mathrm{C}\right.$ and $\left.160 \mathrm{~Pa} \mathrm{CO}\right)$ conditions were labeled by iTRAQ (isobaric tag for relative and absolute quantitation), followed by tandem mass spectrometry (MS/MS) analysis. Using this approach, 103 differentially expressed proteins were successfully identified among 1701 detected proteins in total. The general trend indicates that the response of the $n p p 1$ mutant to the $\mathrm{HT}+\mathrm{ECO}_{2}$ treatment is due, at least partly, to changes in the expression of proteins from the following groups: photosynthesis, carbohydrate metabolism, protein synthesis, and signaling.

\subsection{Photosynthesis and Carbohydrate Metabolism}

Various proteins associated with photosynthesis and carbohydrate metabolism were upregulated in $\mathrm{HT}+\mathrm{ECO}_{2}$ grown npp1 plants (Figure 5A) compared with WT plants (Figure 5B). The $\mathrm{HT}+\mathrm{ECO}_{2}$ treatment promoted the expression of Rubisco activase, a protein that acts as Rubisco's catalytic chaperone [33]. This result is consistent with the enhanced photosynthetic carbon assimilation and also a rise in electron transport capacity. Growth under $\mathrm{HT}+\mathrm{ECO}_{2}$ also upregulated the expression of Calvin-Benson enzymes (e.g., fructose-bisphosphate aldolase (FBPA), phosphoglycerate kinase (PGK), and phosphoribulokinase (PRK)). The data presented thus indicate that the $\mathrm{HT}+\mathrm{ECO}_{2}$ enhancement of photosynthesis in npp1 is the result of enhanced enzymatic activities involved in $\mathrm{CO}_{2}$ fixation.

The starch synthesis-related enzymes, G1P adenylyltransferase (AGPase), sucrose synthase (SuSy), and 4- $\alpha$-glucanotransferase protein (DPE2), exhibited a clear upregulation under $\mathrm{HT}+\mathrm{ECO}_{2}$. AGPase is produced from ATP and glucose 1-phosphate to the ADP-glucose necessary for starch biosynthesis. SuSy is responsible for the conversion of sucrose and a nucleoside diphosphate into the corresponding nucleoside diphosphate glucose and fructose, however, this sucrolytic protein may participate in the direct conversion of sucrose into ADP-glucose linked to starch biosynthesis. The sucrose and starch metabolic pathways are tightly interconnected by means of cytosolic ADP-glucose producing enzymes such as SuSy and by the action of an ADP-glucose translocator located on the chloroplast envelope membranes [10,34]. Furthermore, the levels of cytosolic glucanotransferase DPE2 involved in the conversion of starch into sucrose [35] were high in npp1 leaves under $\mathrm{HT}+\mathrm{ECO}_{2}$ conditions. The high expression of AGPase, SuSy, and DPE2 induced under $\mathrm{HT}+\mathrm{ECO}_{2}$ conditions would be crucial factors for carbohydrate accumulation.

\subsection{Protein Synthesis System}

The marked upregulation of a large set of proteins related to the protein synthesis system when knocking out npp1 was also produced by the enhancement of temperature and $\mathrm{CO}_{2}$ (Figure $5 \mathrm{C}$ ), although such an increase was not observed in WT leaves (Figure 5D). Ribosome components such as 60S, 50S, 40S, and 30S ribosomal proteins were identified as being upregulated. In addition, elongation factor 1 (EF-I $\alpha$ and $\beta), 2, \mathrm{~T}$ (EF-Ts and $-\mathrm{Tu})$, and four rice eukaryotic initiation factor proteins (eIF 3A, eIF 3F, eIF4A, and eIF4F) were increased in $n p p 1$ under HT $+\mathrm{ECO}_{2}$. EF-I $\alpha$ controls GTP-binding proteins responsible for cytoskeletal tubulin, which is positively correlated with starch accumulation [36]. Early studies showed that EF-I $\alpha$ can influence the organization of cytoskeletal components surrounding protein bodies around the endoplasmic reticulum membranes, which appear to reorganize coincident with the actively accumulating storage proteins in the endosperm [37]. eIF participates in most translation initiation processes and plays important roles in the growth and development (and organ size) of Arabidopsis and rice [38-40]. 
A

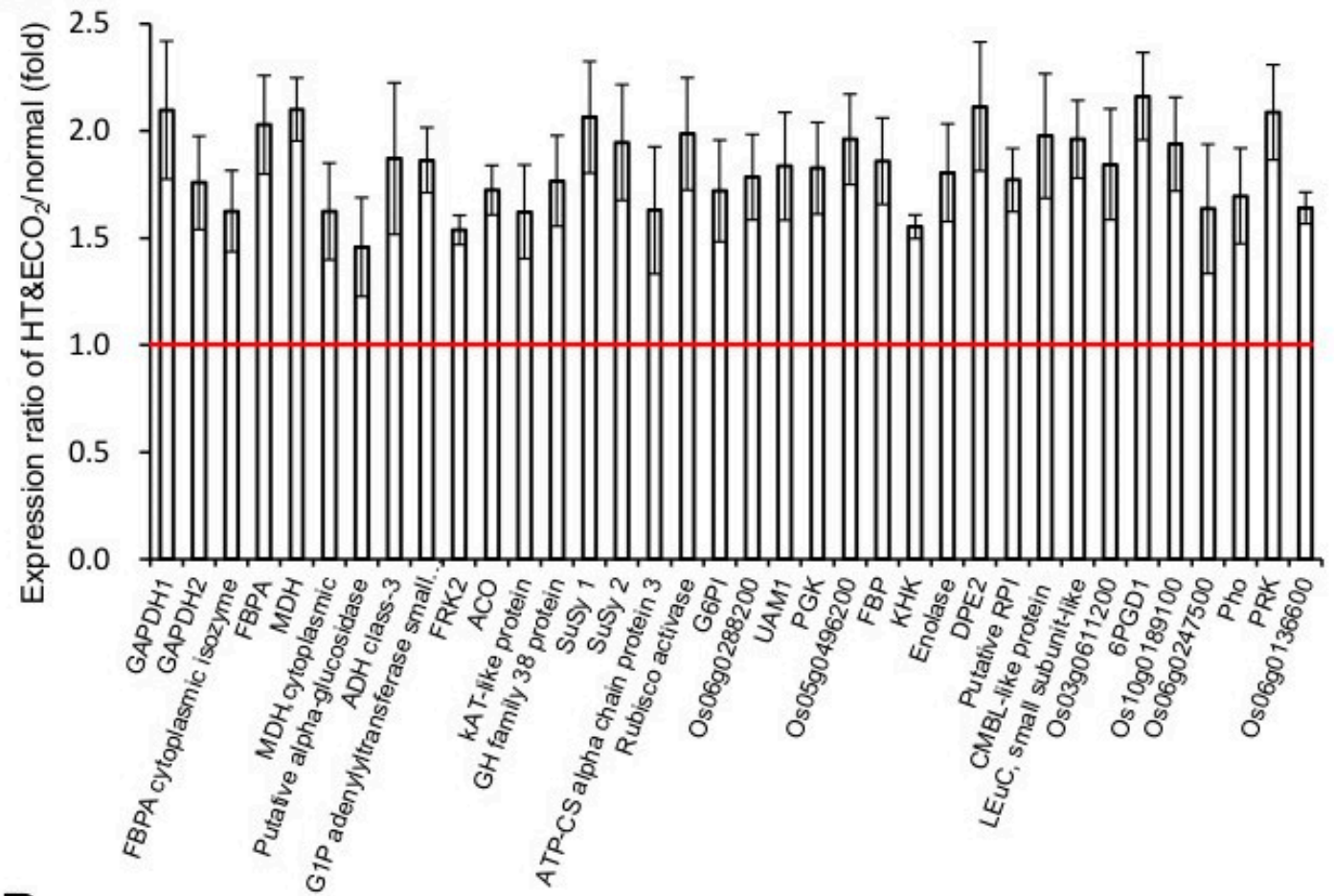

B

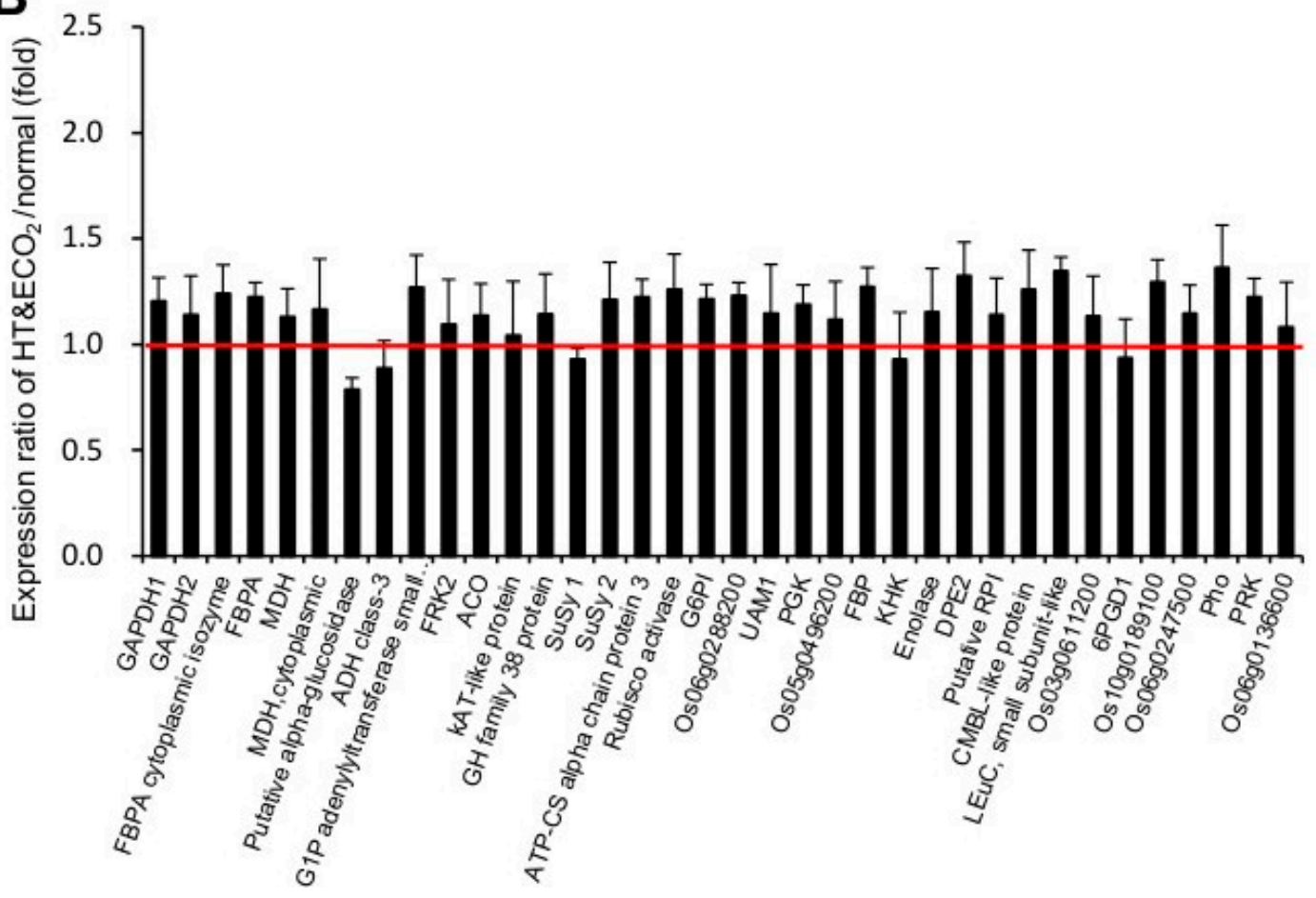

Figure 5. Cont. 
C
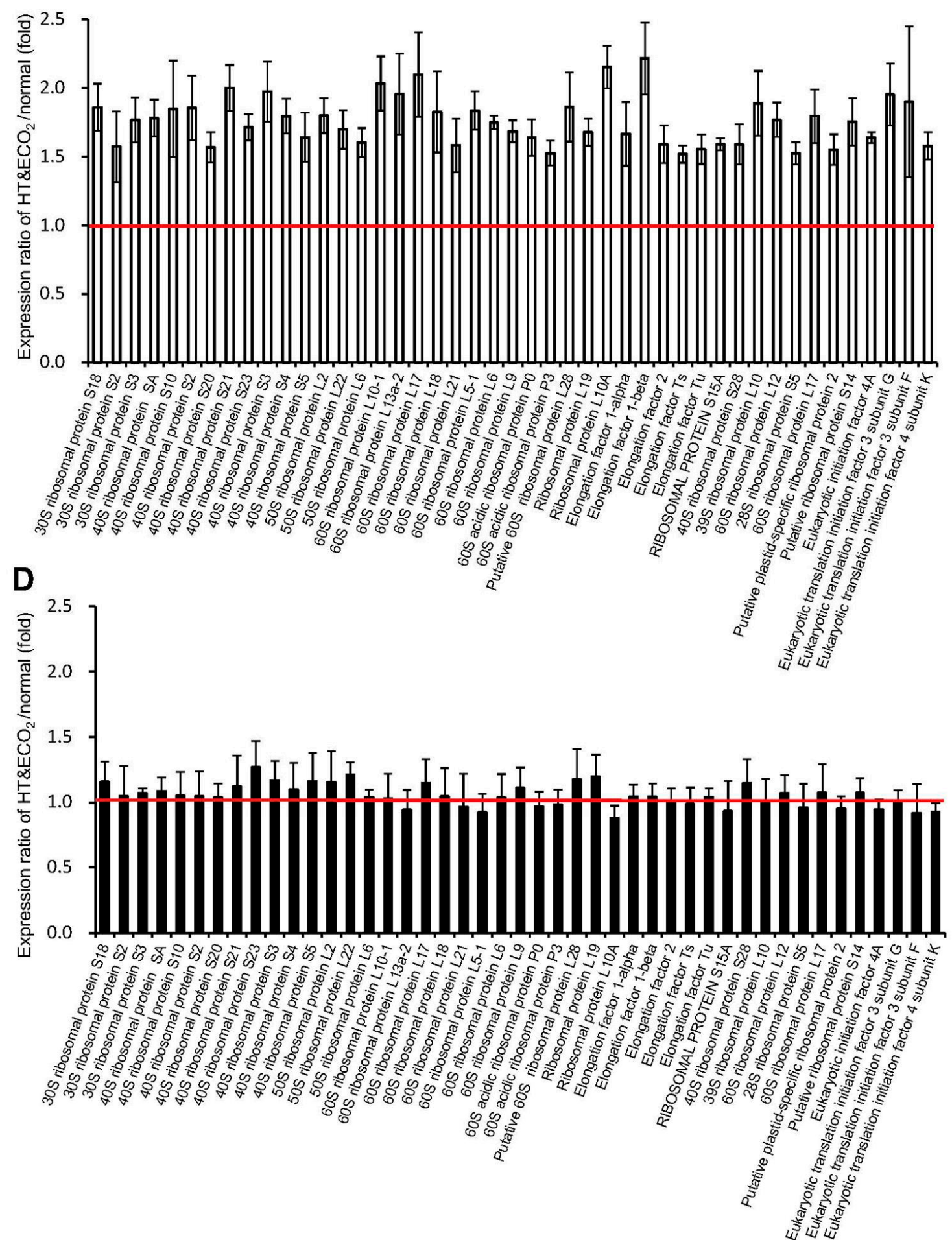

Figure 5. Changes in the expression of carbohydrate- and protein synthesis-related proteins in leaves of WT and npp1 mutant plants under high temperature and elevated $\mathrm{CO}_{2}$ concentrations. The leaves of $\mathrm{WT}(\mathbf{B}, \mathbf{D})$ and $n p p 1(\mathbf{A}, \mathbf{C})$ plants were incubated under normal $\left(28 / 23^{\circ} \mathrm{C}, 40 \mathrm{~Pa} \mathrm{CO}_{2}\right)$ and $\mathrm{HT}+\mathrm{ECO}_{2}$ $\left(33 / 28^{\circ} \mathrm{C}, 160 \mathrm{~Pa} \mathrm{CO}_{2}\right)$ conditions, and then subjected to a proteomic analysis with Isobaric tags for relative and absolute quantitation (iTRAQ) labeling. Values show the means \pm s.d. $(n=3)$. The red line shows the ratio between $\mathrm{HT}+\mathrm{ECO}_{2} /$ normal condition mean equal to 1 . 


\subsection{Signaling}

Several 14-3-3 proteins exhibited significant changes in npp1 mutants under $\mathrm{HT}+\mathrm{ECO}_{2}$ conditions (Figure 6) and were thus deemed to play important roles in starch biosynthesis in rice leaves. In this study, the upregulation of three 14-3-3 isoforms (14-3-3 GF14C, 14-3-3 GF14E, and 14-3-3 GF14F) was detected, suggesting changes in the phosphorylation status in npp1 mutants. Recently, the ectopic overexpression of the cassava 14-3-3 gene in Arabidopsis showed an increase in starch content in the leaves from transgenic plants [36]. A striking feature of the 14-3-3 proteins is their ability to bind a multitude of functionally diverse signaling proteins, including kinases, phosphatases, and transmembrane receptors [41], and 14-3-3 proteins play roles in regulating plant development and stress responses by effecting direct protein-protein interactions [42-44]. The interactions with 14-3-3s are subject to environmental control through signaling pathways that impact on 14-3-3 binding sites. The phosphoserine/threonine-binding 14-3-3 proteins participate in environmentally responsive phosphorylation-linked regulatory functions in plants and are potentially involved in starch regulation [45]. Previous studies have identified the protein-protein interactions between 14-3-3 and key enzymes of primary metabolism (e.g., sucrose-phosphate synthase and glyceraldehyde-3-phosphate dehydrogenase) and showed the central role of 14-3-3s as regulators of enzymes of cytosolic metabolism and ion pumps [46-49]. A molecular genetic analysis of 14-3-3 isoforms using overexpressed and knockout plants with studies of protein-protein interactions revealed alterations in the level of metabolic intermediates of glycolysis, tricarboxylic acid (TCA), and biosynthesis of aromatic compounds [50]. Hence, we may speculate that 14-3-3 may play a role in the accumulation of starch in $n p p 1$ mutants by interacting with metabolic enzymes and thus appears to maintain those enzymes in an active state in the cell. Notably, 14-3-3 proteins have been localized to the chloroplast stroma and the stromal side of thylakoid membranes [51], thereby implicating a potential role in starch regulation.

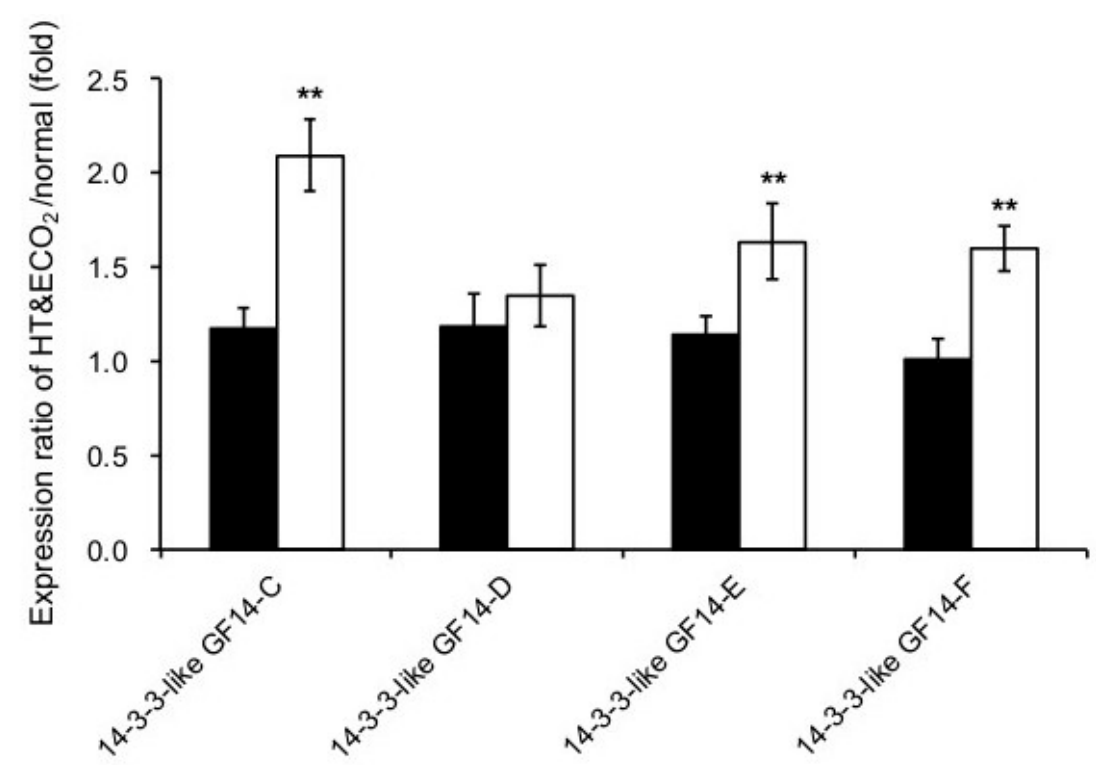

Figure 6. Changes in expression of 14-3-3 proteins in leaves of WT and npp1 mutant plants under high temperature and elevated $\mathrm{CO}_{2}$ concentrations. Details of incubation conditions via a proteomic analysis were described in Figure 5. The leaves of WT (filled bars) and npp1 (open bars) plants were incubated under normal and $\mathrm{HT}+\mathrm{ECO}_{2}$ conditions. Values show the means \pm s.d. $(n=3)$. Asterisks indicate significant differences by Student's $t$-test $\left.{ }^{* *}, p>0.01\right)$.

Photosynthesis, sugar assays, and quantitative proteomic analyses of leaves of knockout npp 1 revealed that the mutant plants always become highly active regardless of normal or $\mathrm{HT}$ and $\mathrm{ECO}_{2}$ conditions (Figures 3-5). The higher $A_{n}$ in npp1 mutants could be the consequence of various 
factors: (i) higher $\mathrm{CO}_{2}$ diffusion; (ii) more efficient conversion of light energy into ATP; and (iii) the upregulation of photosynthetic enzymes (Rubisco activase and Calvin-Benson enzymes). We consider that an activation effector would be the high level of ATP in chloroplasts, since NPP1 preferentially hydrolyzes ATP [14]. Of note, a series of 14-3-3 proteins were upregulated in npp 1 mutants (Figure 6), suggesting that the protein phosphorylation status is possibly changed by the disruption of the NPP1 gene. Phosphorylation of proteins in chloroplasts plays a major role in regulating both the light and dark reactions of photosynthesis. Light-harvesting chlorophyll a/b binding proteins [52-54], Rubisco [55], Rubisco activase [56], phosphoglycerate kinase [57], Glyceraldehyde 3-phosphate dehydrogenase (GAPDH) [58], and transketolase [59] were shown to be phosphorylated and the enzyme functions were regulated. In addition, sigma factor [60] and 24/28 RNA binding proteins [61] were also phosphorylated.

We analyzed the phosphorylation state of WT and npp 1 chloroplast proteins under HT and $\mathrm{ECO}_{2}$ conditions by employing $\mathrm{TiO}_{2}$ chromatography and mass spectrometry. The phosphopeptides derived from chlorophyll $\mathrm{a} / \mathrm{b}$ binding protein, Rubisco large chain, pyruvate phosphate dikinase, and some other plastidial enzymes and proteins were detected with good reproducibility. The level of protein phosphorylation in npp 1 chloroplasts under $\mathrm{HT}$ and $\mathrm{ECO}_{2}$ was higher than that of npp 1 under the normal condition or the WT chloroplasts (Table 1). The chlorophyll a/b binding protein is the main component of the light-harvesting complex (LHC), which is a light receptor that captures and delivers excitation energy to photosystems PSI and PSII. The reversible phosphorylation of light harvesting chlorophyll a/b binding proteins (LHCII) has been observed, which regulates state transitions for balancing the excitation energy between PSI and PSII [54,62]. As shown in Table 1, several phosphorylation sites of chlorophyll $\mathrm{a} / \mathrm{b}$ binding proteins in the $n p p 1$ mutant were more highly phosphorylated in comparison with the WT chloroplasts. In addition, the phosphorylation level of chlorophyll a/b binding proteins in both npp 1 and WT were increased under $\mathrm{HT}$ and $\mathrm{ECO}_{2}$ conditions. In our phosphoproteomic analysis, two phosphopeptides plastid movement impaired1 (PMI1) and plastid transcriptionally active 16 (pTac16) were found to be more abundant under $\mathrm{ECO}_{2}+\mathrm{HT}$ condition in npp1 mutant plants. The PMI1 is a plant-specific C2-domain protein that plays a role in organelle movement and positioning [63]. The movements of npp 1 organelles (i.e chloroplasts) within the cell, which become appropriately positioned under $\mathrm{ECO}_{2}+\mathrm{HT}$, could be a fundamental cellular activity to accomplish their functions and adapt to environmental stress. The pTac16 is a plastid membrane-attached multimeric protein complex involved in plastid transcription and translation. The knockout lines ptac seedlings developed white or yellow cotyledons, failed to accumulate chlorophyll even under low light intensities, impaired plastid structure [64], and downregulated levels of plastid-encoded polymerase (PEP) responsible exclusively for the expression of chloroplast-encoded photosynthetic genes $[65,66]$. The upregulation of pTac 16 in npp 1 mutant plants under $\mathrm{HT}+\mathrm{ECO}_{2}$ could at least partly explain the enhancement of photosynthesis-related genes and activity, and plastid metabolism. Hence, we consider that the high phosphorylation status in $n p p 1$ under $\mathrm{HT}$ and $\mathrm{ECO}_{2}$ could be related to the activation of growth and carbohydrate accumulation of the seedlings.

Table 1. Phosphopeptide detection in WT and npp1 chloroplasts with or without $\mathrm{HT}$ and $\mathrm{ECO}_{2}$ treatment. n.d.: not detected.

\begin{tabular}{cccccc}
\hline Description & Accession & WT Control & WT HT\&ECO $_{2}$ & $n p p 1$ Control & npp1 HT\&ECO \\
\hline Chlorophyll a/b-binding protein & Q6Z411 & $(1.15 \pm 0.78) \times 10^{8}$ & $(2.43 \pm 2.06) \times 10^{8}$ & $(1.05 \pm 0.53) \times 10^{9}$ & $(7.43 \pm 4.27) \times 10^{8}$ \\
Chlorophyll a-b binding protein 2 & P12331 & n.d. & $(4.84 \pm 2.39) \times 10^{6}$ & n.d. & $(4.29 \pm 4.18) \times 10^{6}$ \\
Chlorophyll a-b binding protein & Q7XV11 & $(1.71 \pm 1.01) \times 10^{6}$ & $(3.83 \pm 0.95) \times 10^{6}$ & $(1.10 \pm 0.44) \times 10^{7}$ & $(9.44 \pm 4.78) \times 10^{6}$ \\
Ribulose bisphosphate carboxylase large chain & P0C512 & $(1.08 \pm 0.97) \times 10^{7}$ & n.d. & $(1.52 \pm 0.29) \times 10^{7}$ & $(1.04 \pm 0.78) \times 10^{7}$ \\
ATP synthase subunit beta & P12085 & $(3.65 \pm 2.51) \times 10^{6}$ & n.d. & n.d. & n.d. \\
PLASTID TRANSCRIPTIONALLY ACTIVE 16 & Q0DJF9 & $(2.55 \pm 1.90) \times 10^{7}$ & $(2.05 \pm 1.54) \times 10^{7}$ & $(0.81 \pm 1.17) \times 10^{7}$ & $(5.19 \pm 7.87) \times 10^{7}$ \\
protein CURVATURE THYLAKOID 1A & Q5Z6P4 & $(8.76 \pm 1.51) \times 10^{7}$ & $(3.11 \pm 0.67) \times 10^{7}$ & $(2.55 \pm 0.04) \times 10^{7}$ & $(6.79 \pm 4.23) \times 10^{7}$ \\
PLASTID MOVEMENT IMPAIRED1 & Q0IZR7 & n.d. & n.d. & n.d. & $(4.16 \pm 1.49) \times 10^{6}$ \\
Pyruvate, phosphate dikinase 1 & Q6AVA8 & $(3.35 \pm 2.78) \times 10^{5}$ & $(4.62 \pm 0.02) \times 10^{5}$ & $(1.35 \pm 1.24) \times 10^{6}$ & n.d. \\
\hline
\end{tabular}




\section{Material and Methods}

\subsection{Plant Material and Growth Condition}

The rice variety used in this study was Oryza sativa L. cv. Nipponbare. The Tos17-inserted line of NPP1 (ND8012) was obtained from the National Institute of Agrobiological Sciences (NIAS, Tsukuba, Japan; [67]), and the npp1-1-1 line with a single copy of Tos17 inserted into the NPP1 gene was established previously. WT and npp1 mutant plants were grown and harvested at Niigata University paddy field (Niigata, Japan).

WT and npp1 mutant seeds were grown in a commercial soil (Kumiai Gousei Baido 3, JA, Tokyo, Japan) in plastic pots and incubated in the growth chamber (CFH-415, Tomy Seiko, Tokyo, Japan) at $28^{\circ} \mathrm{C}(14 \mathrm{~h}$ day $) / 23{ }^{\circ} \mathrm{C}(10 \mathrm{~h}$ night $)$ cycles with fluorescent lighting $\left(300 \mu \mathrm{mol} \cdot \mathrm{m}^{-2} \cdot \mathrm{s}^{-1}\right)$. Seeds and plant samples were stored at $4{ }^{\circ} \mathrm{C}$ before analysis.

\subsection{Thermal Imaging}

Thermal images of WT and npp1 mutant plants were obtained using the InfRec (NEC) thermal video system. Plants grown for 60 days on soil (Kumiai Gousei Baido 3) were transferred to Biotron LPH-1.5PH-NCII (length $4.5 \times$ width $4.5 \times$ height 1.8-2.2 m, Nihon-ika, Osaka, Japan) and incubated under four different conditions $\left(28^{\circ} \mathrm{C}, 40 \mathrm{~Pa} \mathrm{CO}_{2} ; 28^{\circ} \mathrm{C}, 160 \mathrm{~Pa} \mathrm{CO}_{2} ; 33^{\circ} \mathrm{C}, 40 \mathrm{~Pa} \mathrm{CO} ; 33{ }^{\circ} \mathrm{C} / 160 \mathrm{~Pa}\right.$ $\left.\mathrm{CO}_{2}\right)$ at $70 \%$ relative humidity under natural light.

\subsection{Gas Exchange Measurements}

Photosynthetic rate $\left(A_{n}\right)$, leaf conductance $\left(g_{s}\right)$, and intercellular $\mathrm{CO}_{2}$ concentrations $\left[\mathrm{CO}_{2}\right]\left(C_{i}\right)$ were measured with a portable photosynthesis LI-6400XL system (LI-6400-20, LiCor Biosciences, Lincoln, NE, USA). Gas exchange of WT and npp1 leaves was recorded in the central segment of top leaves attached to the main culm between 3 and $8 \mathrm{~h}$ after the start of the photoperiod. Leaf cuvette conditions were set as follows: block temperature was set at ambient (growth chamber; $28^{\circ} \mathrm{C}$ ) and high $\left(33^{\circ} \mathrm{C}\right)$ temperatures; $\left[\mathrm{CO}_{2}\right]$ was set at 400 to $2000 \mu \mathrm{mol} \cdot \mathrm{mol}^{-1}$; relative humidity was maintained equal to that in the growth chamber; and Photosynthetically Active Radiation (PAR) was set at $1200 \mu \mathrm{mol} \cdot \mathrm{m}^{-2} \cdot \mathrm{s}^{-1}$, resulting in light-saturated photosynthesis and no decline as a result of photorespiration.

\subsection{Assay}

Sucrose content was measured according to the methods described previously [18,68]. Chlorophyll extracted from the isolated chloroplasts with $80 \%(v / v)$ acetone was assayed by the method described by Porra et al. [69]. Protein concentration was determined by the Pierce 660 nm Protein Assay Kit (Thermo Fisher Scientific, Waltham, MA, USA) using bovine serum albumin (BSA) as a standard.

\subsection{Analysis of Leaf Proteome}

Two hundred milligrams of leaves of WT and npp1 grown for 7 days under normal $\left(28^{\circ} \mathrm{C}, 14 \mathrm{~h}\right.$ day $/ 23{ }^{\circ} \mathrm{C}, 10 \mathrm{~h}$ night, $\left.40 \mathrm{~Pa} \mathrm{CO}_{2}\right)$ and elevated temperature and $\mathrm{CO}_{2}\left(33^{\circ} \mathrm{C}, 14 \mathrm{~h}\right.$ day $/ 28{ }^{\circ} \mathrm{C}, 10 \mathrm{~h}$ night, $160 \mathrm{~Pa} \mathrm{CO}_{2}$ ) conditions were ground in liquid nitrogen and suspended in $7 \mathrm{M}$ urea, $2 \mathrm{M}$ thiourea, 3\% ( $w / v)$ CHAPS (3-((3-cholamidopropyl) dimethylammonio)-1-propanesulfonate), 1\% ( $v / v)$ Triton $\mathrm{X}-100$, and $10 \mathrm{mM}$ dithiothreitol. After centrifugation at $10,000 \times \mathrm{g}$ at $4{ }^{\circ} \mathrm{C}$ for $5 \mathrm{~min}$, the supernatants were mixed with $1 / 10$ volume of $100 \%(w / v)$ TCA, incubated on ice for $15 \mathrm{~min}$, and then centrifuged at $10,000 \times g$ at $4{ }^{\circ} \mathrm{C}$ for $15 \mathrm{~min}$. The resulting precipitates were washed three times with ice-cold acetone and resuspended in $8 \mathrm{M}$ urea.

The procedure of quantitative shotgun proteomic analysis was the same as previously described [68]. The protein samples $(50 \mu \mathrm{g})$ were thoroughly digested with endoproteinase Lys-C and trypsin at $37^{\circ} \mathrm{C}$ for $12 \mathrm{~h}$. iTRAQ labeling of peptides was carried out with 4-plex iTRAQ tags 
according to the manufacturer's protocol (AB Sciex, Framingham, MA, USA), and the resultant 4-iTRAQ-labeled peptide samples were mixed. iTRAQ analysis was performed by employing a DiNa-A-LTQ-Orbitrap-XL system operated with Xcalibur 2.0 software (Thermo Fisher Scientific). Proteins were identified with Proteome Discoverer v. 1.4 software, and the SEQUEST HT (Thermo Fisher Scientific) and MsAmanda [70] search tool using the UniProt (http://www.uniprot.org/) O. sativa subsp. japonica database (63,535 proteins) with the following parameters: enzyme, trypsin; maximum missed cleavages site, 2; peptide charge, 2+ or 3+; MS tolerance, $5 \mathrm{ppm}$; MS/MS tolerance, $\pm 0.5 \mathrm{Da}$; dynamic modification, carboxymethylation $(\mathrm{C})$, oxidation $(\mathrm{H}, \mathrm{M}, \mathrm{W})$, iTRAQ 4-plex $(\mathrm{K}, \mathrm{Y}$, $\mathrm{N}$-terminus). False discovery rates were $<1 \%$.

The mass spectrometry proteomics data (JPST000338) have been deposited in the jPOST repository (https://repository.jpostdb.org/).

\subsection{Analysis of Chloroplast Phosphoproteome}

The procedure of chloroplast isolation was essentially identical to the method described earlier [16,71]. Rice seeds were germinated and grown for 7 days under normal $\left(28^{\circ} \mathrm{C}, 14 \mathrm{~h}\right.$ day $/ 23^{\circ} \mathrm{C}$, $10 \mathrm{~h}$ night, $\left.40 \mathrm{~Pa} \mathrm{CO}_{2}\right)$ and elevated temperature and $\mathrm{CO}_{2}\left(33^{\circ} \mathrm{C}, 14 \mathrm{~h}\right.$ day $/ 28^{\circ} \mathrm{C}, 10 \mathrm{~h}$ night, $160 \mathrm{~Pa}$ $\mathrm{CO}_{2}$ ) conditions. Thirty grams of leaves were homogenized with an equal volume of solution $\mathrm{A}$ mixture consisting of $50 \mathrm{mM}$ HEPES-KOH pH 7.5, $0.33 \mathrm{M}$ sorbitol, $5 \mathrm{mM} \mathrm{MgCl}_{2}, 5 \mathrm{mM} \mathrm{MnCl}_{2}$ and $5 \mathrm{mM}$ EDTA (ethylenediaminetetraacetic acid), $50 \mathrm{mM}$ sodium ascorbate, and then the homogenates were passed through four layers of gauze and four layers of Miracloth (Merck, Darmstadt, Germany). The filtrate was layered onto an $80 \%(v / v)$ Percoll (Sigma, St.Louis, USA) cushion containing solution A, and centrifuged at $2000 \times g$ at $4{ }^{\circ} \mathrm{C}$ for $4 \mathrm{~min}$. The crude chloroplasts on the Percoll surface were diluted with more than twice the volume of solution $\mathrm{A}$, then layered onto a discontinuous density gradient consisting of $40 \%$ and $80 \%$ Percoll solutions. The gradient was centrifuged at $4000 \times g$ at $4{ }^{\circ} \mathrm{C}$ for $10 \mathrm{~min}$. Intact chloroplasts enriched around the $40 \% / 80 \%$ Percoll interface were collected and subjected again to the Percoll gradient centrifugation. Intact chloroplasts were diluted with five times the volume of solution $\mathrm{A}$, and centrifuged at $2000 \times \mathrm{g}$ at $4{ }^{\circ} \mathrm{C}$ for $4 \mathrm{~min}$, followed by chlorophyll and protein extractions.

Analyses of phosphoproteins were carried out according to the method described by Fukuda et al. [72]. Intact chloroplasts were suspended in $7 \mathrm{M}$ urea, $2 \mathrm{M}$ thiourea, $3 \%(w / v)$ CHAPS, $1 \%(v / v)$ Triton $\mathrm{X}-100$, and $10 \mathrm{mM}$ dithiothreitol. After centrifugation at $10,000 \times g$ at $4{ }^{\circ} \mathrm{C}$ for $5 \mathrm{~min}$, the supernatants were mixed with $1 / 10$ volume of $100 \%(w / v)$ TCA, incubated on ice for $15 \mathrm{~min}$, and then centrifuged at $10,000 \times \mathrm{g}$ at $4{ }^{\circ} \mathrm{C}$ for $15 \mathrm{~min}$. The resulting precipitates were washed three times with ice-cold acetone and resuspended in $8 \mathrm{M}$ urea. The protein preparations $(100 \mu \mathrm{g})$ were digested with $2 \%(w / w)$ endoproteinase Lys-C and trypsin in $25 \mathrm{mM} \mathrm{NH}_{4} \mathrm{HCO}_{3}$ and $0.8 \mathrm{M}$ urea at $37^{\circ} \mathrm{C}$ for $12 \mathrm{~h}$. The reaction mixtures were dried on a Centrifugal Concentrator (CC-105, Tomy, Japan) and then dissolved in buffer A consisting of $60 \%(v / v)$ acetonitrile $(\mathrm{ACN}), 5 \%(v / v)$ glycerol, $0.1 \%$ $(v / v)$ Trifluoroacetic acid (TFA). A MonoSpin TiO column (1000 $\mu$ L: GL Science, Tokyo, Japan) was pre-equilibrated with buffer B consisting of $80 \%(v / v)$ ACN, $0.1 \%(v / v)$ TFA, followed by buffer A, and the samples were centrifuged at $3000 \times g$ for 1 min each. The obtained peptide samples were applied to the tip column and centrifuged at $3000 \times g$ for $5 \mathrm{~min}$. The flow-through fraction was applied to the tip column again. Subsequently, the tip column was washed three times with buffer A and centrifuged at $3000 \times g$ for $1 \mathrm{~min}$. The binding phosphopeptides were eluted with $100 \mu \mathrm{L}$ of $5 \% \mathrm{NH}_{4} \mathrm{OH}$ with centrifugation at $1000 \times g$ for $5 \mathrm{~min}$. After elution with $5 \% \mathrm{NH}_{4} \mathrm{OH}$, the tightly binding phosphopeptides were eluted with $100 \mu \mathrm{L}$ of $1 \mathrm{M}(w / v)$ bis-Tris propane with centrifugation at $1000 \times g$ for $1 \mathrm{~min}$. The phosphopeptides eluted with $5 \% \mathrm{NH}_{4} \mathrm{OH}$ solution were dried on a Centrifugal Concentrator and then dissolved in 5\% $(v / v)$ formic acid (FA). The phosphopeptides eluted with $1 \mathrm{M}$ bis-Tris propane were acidified with $900 \mu \mathrm{L}$ of $5 \%$ FA and then desalted using a MonoSpin C18 column (GL Sciences, Tokyo, Japan). 
Each phospho-peptide fraction was loaded on a HiQ sil C-18 W-3 trap column with buffer C consisting of $0.1 \%(v / v)$ FA and $2 \%(v / v)$ ACN using a DiNa-A system (KYA Tech., Tokyo, Japan). A linear gradient from $0 \%$ to $33 \%$ buffer D consisting of $0.1 \%$ FA and $80 \% \mathrm{ACN}$ for $600 \mathrm{~min}, 33 \%$ to $100 \% \mathrm{D}$ for $10 \mathrm{~min}$ and back to $\%$ D in 15 min was applied, and peptides eluted from the HiQ sil C-18 W-3 column were directly loaded on a MonoCap C18 High Resolution 2000 separation column. The separated peptides were introduced into a LTQ-Orbitrap XL mass spectrometer (Thermo Fisher Scientific, Waltham, MA, USA) with a flow rate of $300 \mathrm{~nL} \cdot \mathrm{min}^{-1}$ and an ionization voltage of $1.7-2.5 \mathrm{kV}$. The mass range selected for MS scan was set to 350-1600 $\mathrm{m} / \mathrm{z}$ and the top five peaks were subjected to MS/MS analysis. The full MS scan was detected in the Orbitrap, and the MS/MS scans were detected in the linear ion trap. The normalized collision energy for MS/MS was set to $35 \mathrm{eV}$ for collision-induced dissociation (CID).

Operation of protein identification with software and database was carried out as described above [68]. The phosphorylation of $\mathrm{S} / \mathrm{T} / \mathrm{Y}$ and oxidation of $\mathrm{H} / \mathrm{M} / \mathrm{W}$ residues were set as dynamic modifications. False discovery rates were $<1 \%$.

The chloroplast phosphoproteome data (JPST000462) have been deposited in the jPOST repository (https://repository.jpostdb.org/).

\section{Conclusions}

Previous investigations have revealed that NPP1 exerts a negative effect on starch accumulation and growth. NPP1 localizes to the chloroplasts and degrades a number of nucleotides including ADP-glucose and ATP, thus, it is possibly a kind of room (for example, chloroplast stroma) cleaning enzyme. The molecular physiological phenotype of the npp1 mutant was further analyzed in the present study. Lower temperatures and changes in the transpiration rates of npp1 leaves were observed, indicating that the disruption of the NPP1 gene caused the stomatal opening of rice leaves. Furthermore, the analysis of the $A_{n} / C_{\mathrm{i}}$ curve indicated that the enhancement of photosynthesis in $n p p 1$ resulted from multiple causes in addition to the stomatal conductance. The proteome of carbohydrate metabolism and protein synthesizing system in npp1 leaves was strongly upregulated by HT and $\mathrm{ECO}_{2}$. Furthermore, the protein phosphorylation status in $n p p 1$ chloroplasts was significantly higher than in WT chloroplasts. An increase in ATP in chloroplasts might be a key stimulus, because NPP1 preferentially hydrolyzes ATP. Judging from the overall results, we consider that the remarkable enhancement of plant growth and carbohydrate accumulation in npp1 mutant plants under HT and $\mathrm{ECO}_{2}$ conditions was a consequence of the non-controlled activation of photosynthesis and protein synthesis by loss of function of a fine-tuning enzyme NPP1.

Author Contributions: T.M. (Toshiaki Mitsui) conceived and designed the project. T.I., T.M. (Takahiro Masui), K.K., T.K., and T.T. (Toshiaki Mitsui) performed the experiments. T.M. (Toshiaki Mitsui) and M.B. supervised and interpreted the data. T.M., M.B., and J.P.-R. wrote the manuscript. All authors discussed the results and implications and commented on the manuscript at all stages.

Funding: This research was supported by Grants-in-Aid for Scientific Research (A) (15H02486) and Strategic International Collaborative Research Program by the Japan Science and Technology Agency (JST SICORP).

Conflicts of Interest: The authors declare that the research was conducted in the absence of any commercial or financial relationships that could be construed as potential conflicts of interest.

\section{References}

1. Ray, D.K.; Gerber, J.S.; MacDonald, G.K.; West, P.C. Climate variation explains a third of global crop yield variability. Nat. Commun. 2015, 6. [CrossRef] [PubMed]

2. Becklin, K.M.; Anderson, J.T.; Gerhart, L.M.; Wadgymar, S.M.; Wessinger, C.A.; Ward, J.K. Examining plant physiological responses to climate change through an evolutionary Lens. Plant Physiol. 2016, 172, 635-649. [CrossRef] [PubMed]

3. Becklin, K.M.; Walker, S.M.; Way, D.A.; Ward, J.K. $\mathrm{CO}_{2}$ studies remain key to understanding a future world. New Phytol. 2017, 214, 34-40. [CrossRef] [PubMed] 
4. Hirasawa, T.; IIda, Y.; Ishihara, K. Effect of leaf water potential and air humidity on photosynthetic rate and diffusive conductance in rice plants. Jpn. J. Crop Sci. 1988, 57, 112-118. [CrossRef]

5. Ishihara, K.; Saitoh, K. Diurnal courses of photosynthesis, transpiration, and diffusive conductance in the single-leaf of the rice plants grown in the paddy field under submerged condition. Jpn. J. Crop Sci. 1987, 56, 8-17. [CrossRef]

6. Negi, J.; Matsuda, O.; Nagasawa, T.; Oba, Y.; Takahashi, H.; Kawai-Yamada, M.; Uchimiya, H.; Hashimoto, M.; $\mathrm{Iba}, \mathrm{K} . \mathrm{CO}_{2}$ regulator SLAC1 and its homologues are essential for anion homeostasis in plant cells. Nature 2008, 452, 483-486. [CrossRef] [PubMed]

7. Kusumi, K.; Chono, Y.; Shimada, H.; Gotoh, E.; Tsuyama, M.; Iba, K. Chloroplast biogenesis during the early stage of leaf development in rice. Plant Biotechnol. 2010, 27, 85-90. [CrossRef]

8. Ishimaru, K. Identification of a locus increasing rice yield and physiological analysis of its function. Plant Physiol. 2003, 133, 1083-1090. [CrossRef] [PubMed]

9. Scofield, G.N.; Hirose, T.; Aoki, N.; Furbank, R.T. Involvement of the sucrose transporter, OsSUT1, in the long-distance pathway for assimilate transport in rice. J. Exp. Bot. 2007, 58, 3155-3169. [CrossRef] [PubMed]

10. Bahaji, A.; Li, J.; Sánchez-López, Á.M.; Baroja-Fernández, E.; Muñoz, F.J.; Ovecka, M.; Almagro, G.; Montero, M.; Ezquer, I.; Etxeberria, E.; et al. Starch biosynthesis, its regulation and biotechnological approaches to improve crop yields. Biotechnol. Adv. 2014, 32, 87-106. [CrossRef] [PubMed]

11. Ball, S.G.; Morell, M.K. From bacterial glycogen to starch: Understanding the Biogenesis of the Plant Starch Granule. Annu. Rev. Plant Biol. 2003, 54, 207-233. [CrossRef] [PubMed]

12. Rodriguez-López, M.; Baroja-Fernández, E.; Zandueta-Criado, A.; Pozueta-Romero, J. Adenosine diphosphate glucose pyrophosphatase: A plastidial phosphodiesterase that prevents starch biosynthesis. Proc. Natl. Acad. Sci. USA 2000, 97, 8705-8710. [CrossRef] [PubMed]

13. Nanjo, Y.; Oka, H.; Ikarashi, N.; Kaneko, K.; Kitajima, A.; Mitsui, T.; Muñoz, F.J.; Rodríguez-López, M.; Baroja-Fernández, E.; Pozueta-Romero, J. Rice plastidial N-glycosylated nucleotide pyrophosphatase/ phosphodiesterase is transported from the ER-golgi to the chloroplast through the secretory pathway. Plant Cell 2006, 18, 2582-2592. [CrossRef] [PubMed]

14. Kaneko, K.; Inomata, T.; Masui, T.; Koshu, T.; Umezawa, Y.; Itoh, K.; Pozueta-romero, J.; Mitsui, T. Nucleotide Pyrophosphatase/Phosphodiesterase 1 exerts a negative effect on starch accumulation and growth in rice seedlings under high temperature and $\mathrm{CO}_{2}$ concentration conditions. Plant Cell Physiol. 2014, 55, 320-332. [CrossRef] [PubMed]

15. Kaneko, K.; Yamada, C.; Yanagida, A.; Koshu, T.; Umezawa, Y.; Itoh, K.; Hori, H.; Mitsui, T. Differential localizations and functions of rice nucleotide pyrophosphatase/phosphodiesterase isozymes 1 and 3. Plant Biotechnol. 2011, 28, 69-76. [CrossRef]

16. Kaneko, K.; Takamatsu, T.; Inomata, T.; Oikawa, K.; Itoh, K.; Hirose, K.; Amano, M.; Nishimura, S.-I.; Toyooka, K.; Matsuoka, K.; et al. N-glycomic and microscopic subcellular localization analyses of NPP1, 2 and 6 strongly indicate that trans-Golgi compartments participate in the Golgi-to-plastid traffic of nucleotide pyrophosphatase/phosphodiesterases in rice. Plant Cell Physiol. 2016, 57, 1610-1628. [CrossRef] [PubMed]

17. Baslam, M.; Oikawa, K.; Kitajima-koga, A.; Kaneko, K.; Mitsui, T. Golgi-to-plastid trafficking of proteins through secretory pathway: Insights into vesicle-mediated import toward the plastids. Plant Signal. Behav. 2016, 11, e1221558. [CrossRef] [PubMed]

18. Asatsuma, S.; Sawada, C.; Itoh, K.; Okito, M.; Kitajima, A.; Mitsui, T. Involvement of $\alpha$-amylase I-1 in starch degradation in rice chloroplasts. Plant Cell Physiol. 2005, 46, 858-869. [CrossRef] [PubMed]

19. Villarejo, A.; Burén, S.; Larsson, S.; Déjardin, A.; Monné, M.; Rudhe, C.; Karlsson, J.; Jansson, S.; Lerouge, P.; Rolland, N.; et al. Evidence for a protein transported through the secretory pathway en route to the higher plant chloroplast. Nat. Cell Biol. 2005, 7, 1224-1231. [CrossRef] [PubMed]

20. Kitajima, A.; Asatsuma, S.; Okada, H.; Hamada, Y.; Kaneko, K.; Nanjo, Y.; Kawagoe, Y.; Toyooka, K.; Matsuoka, K.; Takeuchi, M.; et al. The rice $\alpha$-amylase glycoprotein is targeted from the Golgi apparatus through the secretory pathway to the plastids. Plant Cell 2009, 21, 2844-2858. [CrossRef] [PubMed]

21. Burén, S.; Ortega-Villasante, C.; Blanco-Rivero, A.; Martínez-Bernardini, A.; Shutova, T.; Shevela, D.; Messinger, J.; Bako, L.; Villarejo, A.; Samuelsson, G. Importance of post-translational modifications for functionality of a chloroplast-localized carbonic anhydrase (CAH1) in Arabidopsis thaliana. PLoS ONE 2011, 6, e21021. [CrossRef] [PubMed] 
22. Shiraya, T.; Mori, T.; Maruyama, T.; Sasaki, M.; Takamatsu, T.; Oikawa, K.; Itoh, K.; Kaneko, K.; Ichikawa, H.; Mitsui, T. Golgi/plastid-type manganese superoxide dismutase involved in heat-stress tolerance during grain filling of rice. Plant Biotechnol. J. 2015, 13, 1251-1263. [CrossRef] [PubMed]

23. Kang, J.S.; Frank, J.; Kang, C.H.; Kajiura, H.; Vikram, M.; Ueda, A.; Kim, S.; Bahk, J.D.; Triplett, B.; Fujiyama, K.; et al. Salt tolerance of Arabidopsis thaliana requires maturation of $N$-glycosylated proteins in the Golgi apparatus. Proc. Natl. Acad. Sci. USA 2008, 105, 5933-5938. [CrossRef] [PubMed]

24. Teskey, R.O.; Fites, J.A.; Samuelson, L.J.; Bongarten, B.C. Stomatal and nonstomatal limitations to net photosynthesis in Pinus taeda L. under different environmental conditions. Tree Physiol. 1986, 2, 131-142. [CrossRef] [PubMed]

25. Sage, R.F.; Sharkey, T.D. The effect of temperature on the occurrence of $\mathrm{O}_{2}$ and $\mathrm{CO}_{2}$ insensitive photosynthesis in field grown plants. Plant Physiol. 1987, 84, 658-664. [CrossRef] [PubMed]

26. Cerasoli, S.; Wertin, T.; McGuire, M.A.; Rodrigues, A.; Aubrey, D.P.; Pereira, J.S.; Teskey, R.O. Poplar saplings exposed to recurring temperature shifts of different amplitude exhibit differences in leaf gas exchange and growth despite equal mean temperature. AoB Plants 2014, 6, plu018. [CrossRef] [PubMed]

27. Von Caemmerer, S.; Evans, J.R. Temperature responses of mesophyll conductance differ greatly between species. Plant. Cell Environ. 2015, 38, 629-637. [CrossRef] [PubMed]

28. Uprety, D.C.; Dwivedi, N.; Jain, V.; Mohan, R. Effect of elevated carbon dioxide concentration on the stomatal parameters of rice cultivars. Photosynthetica 2002, 40, 315-319. [CrossRef]

29. Shimazaki, K.; Iino, M.; Zeiger, E. Blue light-dependent proton extrusion by guard-cell protoplasts of Vicia faba. Nature 1986, 319, 324-326. [CrossRef]

30. Talbott, L.D.; Zeiger, E. The role of sucrose in guard cell osmoregulation. J. Exp. Bot. 1998, 49, 329-337. [CrossRef]

31. Schroeder, J.I.; Hagiwara, S. Cytosolic calcium regulates ion channels in the plasma membrane of Vicia faba guard cells. Nature 1989, 338, 427-430. [CrossRef]

32. Kusumi, K.; Hirotsuka, S.; Kumamaru, T.; Iba, K. Increased leaf photosynthesis caused by elevated stomatal conductance in a rice mutant deficient in SLAC1, a guard cell anion channel protein. J. Exp. Bot. 2012, 63, 5635-5644. [CrossRef] [PubMed]

33. Portis, A. Rubisco Activase-Rubisco's catalytic chaperone. Photosynth. Res. 2003, 75, 11-27. [CrossRef] [PubMed]

34. Li, J.; Baroja-Fernandez, E.; Bahaji, A.; Munoz, F.J.; Ovecka, M.; Montero, M.; Sesma, M.T.; Alonso-Casajus, N.; Almagro, G.; Sanchez-Lopez, A.M.; et al. Enhancing sucrose synthase activity results in increased levels of starch and ADP-glucose in maize (Zea mays L.) seed endosperms. Plant Cell Physiol. 2013, 54, $282-294$. [CrossRef] [PubMed]

35. Lu, Y.; Gehan, J.P.; Sharkey, T.D. Daylength and circadian effects on starch degradation and maltose metabolism. Plant Physiol. 2005, 138, 2280-2291. [CrossRef] [PubMed]

36. Wang, X.; Chang, L.; Tong, Z.; Wang, D.; Yin, Q.; Wang, D.; Jin, X.; Yang, Q.; Wang, L.; Sun, Y.; et al. Proteomics profiling reveals carbohydrate metabolic enzymes and 14-3-3 proteins play important roles for starch accumulation during cassava root tuberization. Sci. Rep. 2016, 6, 19643. [CrossRef] [PubMed]

37. Clore, A.M.; Dannenhoffer, J.M.; Larkins, B.A. EF-1 $\alpha$ is associated with a cytoskeletal network surrounding protein bodies in maize endosperm cells. Plant Cell 1996, 8, 2003-2014. [CrossRef] [PubMed]

38. Yahalom, A.; Kim, T.-H.; Roy, B.; Singer, R.; Von Arnim, A.G.; Chamovitz, D.A. Arabidopsis eIF3e is regulated by the COP9 signalosome and has an impact on development and protein translation. Plant J. 2007, 53, 300-311. [CrossRef] [PubMed]

39. Li, Q.; Deng, Z.; Gong, C.; Wang, T. The rice eukaryotic translation initiation factor 3 subunit $\mathrm{f}$ (OseIF3f) is involved in microgametogenesis. Front. Plant Sci. 2016, 7, 532. [CrossRef] [PubMed]

40. Kim, T.-H.; Kim, B.-H.; Yahalom, A.; Chamovitz, D.A.; von Arnim, A.G. Translational regulation via 5' mRNA leader sequences revealed by mutational analysis of the Arabidopsis translation initiation factor subunit eIF3h. Plant Cell 2004, 16, 3341-3356. [CrossRef] [PubMed]

41. Fu, H.; Subramanian, R.R.; Masters, S.C. 14-3-3 proteins: structure, function, and regulation. Annu. Rev. Pharmacol. Toxicol. 2000, 40, 617-647. [CrossRef] [PubMed]

42. Roberts, M.R.; Salinas, J.; Collinge, D.B. 14-3-3 proteins and the response to abiotic and biotic stress. Plant Mol. Biol. 2002, 50, 1031-1039. [CrossRef] [PubMed] 
43. Wilson, R.S.; Swatek, K.N.; Thelen, J.J. Regulation of the regulators: Post-Translational Modifications, subcellular, and spatiotemporal distribution of plant 14-3-3 proteins. Front. Plant Sci. 2016, 7, 611. [CrossRef] [PubMed]

44. Xu, W.; Jia, L.; Shi, W.; Liang, J.; Zhang, J. Smart role of plant 14-3-3 proteins in response to phosphate deficiency. Plant Signal. Behav. 2012, 7, 1047-1048. [CrossRef] [PubMed]

45. Sehnke, P.C.; Chung, H.J.; Wu, K.; Ferl, R.J. Regulation of starch accumulation by granule-associated plant 14-3-3 proteins. Proc. Natl. Acad. Sci. USA 2001, 98, 765-770. [CrossRef] [PubMed]

46. Baunsgaard, L.; Fuglsang, A.T.; Jahn, T.; Korthout, H.A.; de Boer, A.H.; Palmgren, M.G. The 14-3-3 proteins associate with the plant plasma membrane $\mathrm{H}^{+}$-ATPase to generate a fusicoccin binding complex and a fusicoccin responsive system. Plant J. 1998, 13, 661-671. [CrossRef] [PubMed]

47. Cotelle, V.; Meek, S.E.; Provan, F.; Milne, F.C.; Morrice, N.; MacKintosh, C. 14-3-3s regulate global cleavage of their diverse binding partners in sugar-starved Arabidopsis cells. EMBO J. 2000, 19, 2869-2876. [CrossRef] [PubMed]

48. Moorhead, G.; Douglas, P.; Cotelle, V.; Harthill, J.; Morrice, N.; Meek, S.; Deiting, U.; Stitt, M.; Scarabel, M.; Aitken, A.; et al. Phosphorylation-dependent interactions between enzymes of plant metabolism and 14-3-3 proteins. Plant J. 1999, 18, 1-12. [CrossRef] [PubMed]

49. Toroser, D.; Athwal, G.S.; Huber, S.C. Site-specific regulatory interaction between spinach leaf sucrose-phosphate synthase and 14-3-3 proteins. FEBS Lett. 1998, 435, 110-114. [CrossRef]

50. Diaz, C.; Kusano, M.; Sulpice, R.; Araki, M.; Redestig, H.; Saito, K.; Stitt, M.; Shin, R. Determining novel functions of Arabidopsis 14-3-3 proteins in central metabolic processes. BMC Syst. Biol. 2011, 5, 192. [CrossRef] [PubMed]

51. Sehnke, P.C.; Henry, R.; Cline, K.; Ferl, R.J. Interaction of a plant 14-3-3 protein with the signal peptide of a thylakoid-targeted chloroplast precursor protein and the presence of 14-3-3 isoforms in the chloroplast stroma. Plant Physiol. 2000, 122, 235-242. [CrossRef] [PubMed]

52. Bellafiore, S.; Barneche, F.; Peltier, G.; Rochaix, J.-D. State transitions and light adaptation require chloroplast thylakoid protein kinase STN7. Nature 2005, 433, 892-895. [CrossRef] [PubMed]

53. Bonardi, V.; Pesaresi, P.; Becker, T.; Schleiff, E.; Wagner, R.; Pfannschmidt, T.; Jahns, P.; Leister, D. Photosystem II core phosphorylation and photosynthetic acclimation require two different protein kinases. Nature 2005, 437, 1179-1182. [CrossRef] [PubMed]

54. Pietrzykowska, M.; Suorsa, M.; Semchonok, D.A.; Tikkanen, M.; Boekema, E.J.; Aro, E.-M.; Jansson, S. The light-harvesting chlorophyll a/b binding proteins Lhcb1 and Lhcb2 play complementary roles during state transitions in Arabidopsis. Plant Cell 2014, 26, 3646-3660. [CrossRef] [PubMed]

55. Chen, X.; Zhang, W.; Zhang, B.; Zhou, J.; Wang, Y.; Yang, Q.; Ke, Y.; He, H. Phosphoproteins regulated by heat stress in rice leaves. Proteome Sci. 2011, 9, 37. [CrossRef] [PubMed]

56. Lemeille, S.; Turkina, M.V.; Vener, A.V.; Rochaix, J.-D. Stt7-dependent phosphorylation during state transitions in the green alga Chlamydomonas reinhardtii. Mol. Cell. Proteom. 2010, 9, 1281-1295. [CrossRef] [PubMed]

57. Facette, M.R.; Shen, Z.; Björnsdóttir, F.R.; Briggs, S.P.; Smith, L.G. Parallel proteomic and phosphoproteomic analyses of successive stages of maize leaf development. Plant Cell 2013, 25, 2798-2812. [CrossRef] [PubMed]

58. Baginsky, S. Protein phosphorylation in chloroplasts-A survey of phosphorylation targets. J. Exp. Bot. 2016, 67, 3873-3882. [CrossRef] [PubMed]

59. Rocha, A.G.; Mehlmer, N.; Stael, S.; Mair, A.; Parvin, N.; Chigri, F.; Teige, M.; Vothknecht, U.C. Phosphorylation of Arabidopsis transketolase at Ser 428 provides a potential paradigm for the metabolic control of chloroplast carbon metabolism. Biochem. J. 2014, 458, 313-322. [CrossRef] [PubMed]

60. Shimizu, M.; Kato, H.; Ogawa, T.; Kurachi, A.; Nakagawa, Y.; Kobayashi, H. Sigma factor phosphorylation in the photosynthetic control of photosystem stoichiometry. Proc. Natl. Acad. Sci. USA 2010, 107, 10760-10764. [CrossRef] [PubMed]

61. Vargas-Suárez, M.; Castro-Sánchez, A.; Toledo-Ortiz, G.; González de la Vara, L.E.; García, E.; Loza-Tavera, H. Protein phosphorylation regulates in vitro spinach chloroplast petD mRNA 3 '-untranslated region stability, processing, and degradation. Biochimie 2013, 95, 400-409. [CrossRef] [PubMed]

62. Tikkanen, M.; Aro, E.-M. Integrative regulatory network of plant thylakoid energy transduction. Trends Plant Sci. 2014, 19, 10-17. [CrossRef] [PubMed] 
63. Suetsugu, N.; Higa, T.; Kong, S.-G.; Wada, M. Plastid Movement Impaired1 and Plastid Movement Impaired1-Related1 mediate photorelocation movements of both chloroplasts and nuclei. Plant Physiol. 2015, 169, 1155-1167. [CrossRef] [PubMed]

64. Pfalz, J.; Liere, K.; Kandlbinder, A.; Dietz, K.-J.; Oelmüller, R. pTAC2, -6, and -12 are components of the transcriptionally active plastid chromosome that are required for plastid gene expression. Plant Cell 2006, 18, 176-197. [CrossRef] [PubMed]

65. Gao, Z.-P.; Chen, G.-X.; Yang, Z.-N. Regulatory role of Arabidopsis pTAC14 in chloroplast development and plastid gene expression. Plant Signal. Behav. 2012, 7, 1354-1356. [CrossRef] [PubMed]

66. Gao, Z.-P.; Yu, Q.-B.; Zhao, T.-T.; Ma, Q.; Chen, G.-X.; Yang, Z.-N. A functional component of the transcriptionally active chromosome complex, Arabidopsis pTAC14, interacts with pTAC12/HEMERA and regulates plastid gene expression. Plant Physiol. 2011, 157, 1733-1745. [CrossRef] [PubMed]

67. Miyao, A.; Tanaka, K.; Murata, K.; Sawaki, H.; Takeda, S.; Abe, K.; Shinozuka, Y.; Onosato, K.; Hirochika, H. Target site specificity of the Tos17 retrotransposon shows a preference for insertion within genes and against insertion in retrotransposon-rich regions of the genome. Plant Cell 2003, 15, 1771-1780. [CrossRef] [PubMed]

68. Kaneko, K.; Sasaki, M.; Kuribayashi, N.; Suzuki, H.; Sasuga, Y.; Shiraya, T.; Inomata, T.; Itoh, K.; Baslam, M.; Mitsui, T. Proteomic and glycomic characterization of rice chalky grains produced under moderate and high-temperature conditions in field system. Rice 2016, 9, 26. [CrossRef] [PubMed]

69. Porra, R.J.; Thompson, W.A.; Kriedemann, P.E. Determination of accurate extinction coefficients and simultaneous equations for assaying chlorophylls a and b extracted with four different solvents: Verification of the concentration of chlorophyll standards by atomic absorption spectroscopy. Biochim. Biophys. Acta Bioenerg. 1989, 975, 384-394. [CrossRef]

70. Dorfer, V.; Pichler, P.; Stranzl, T.; Stadlmann, J.; Taus, T.; Winkler, S.; Mechtler, K. MS Amanda, a universal identification algorithm optimized for high accuracy tandem mass spectra. J. Proteome Res. 2014, 13, 3679-3684. [CrossRef] [PubMed]

71. Takamatsu, T.; Baslam, M.; Inomata, T.; Oikawa, K.; Itoh, K.; Ohnishi, T.; Kinoshita, T.; Mitsui, T. Optimized method of extracting rice chloroplast DNA for high-quality plastome resequencing and de novo assembly. Front. Plant Sci. 2018, 9, 266. [CrossRef] [PubMed]

72. Fukuda, I.; Hirabayashi-Ishioka, Y.; Sakikawa, I.; Ota, T.; Yokoyama, M.; Uchiumi, T.; Morita, A. Optimization of enrichment conditions on $\mathrm{TiO}_{2}$ chromatography using glycerol as an additive reagent for effective phosphoproteomic analysis. J. Proteome Res. 2013, 12, 5587-5597. [CrossRef] [PubMed] 